\title{
Mary Broadfoot Walker: 83 years since a historical discovery
}

\author{
Mary Broadfoot Walker: 83 anos desde uma descoberta histórica \\ Vitor Martinez de Carvalho', Eduardo de Almeida Guimarães Nogueira', Gleysson Rodrigues Rosa², Yara \\ Dadalti Fragoso ${ }^{1}$
}

\begin{abstract}
Mary Broadfoot Walker was a Scottish physician who, in 1935, described in great detail the effect of an anticholinesterase drug (physostigmine) on the signs and symptoms of myasthenia gravis. An original five-minutes movie is available online and the skepticism of her contemporary British medical doctors is understandable when the drastic effect of the treatment is shown in this movie. What Mary Walker taught us, more than eight decades ago, about myasthenia gravis continues to be the basis of a pharmacological diagnostic test and treatment of this disease.
\end{abstract}

Keywords: myasthenia gravis; physostigmine; neostigmine; acetylcholinesterase.

\section{RESUMO}

Mary Broadfoot Walker foi uma médica escocesa que em 1935 descreveu em grande detalhe o efeito de uma droga anticolinesterásica (fisostigmina) nos sinais e sintomas da myasthenia gravis. Um filme original com cinco minutos de duração está disponível online e a reação cética dos colegas médicos contemporâneos de Mary é compreensivel dado o drástico efeito terapêutico mostrado neste filme. 0 que Mary Walker nos ensinou mais de oito décadas atrás continua a ser a base de um teste diagnóstico farmacológico e do tratamento da myasthenia gravis.

Palavras-chave: miastenia gravis; fisostigmina; neostigmina; acetilcolinesterase.

Mary Broadfoot Walker was born in Croft-an-Righ, Wigtown, Scotland, and graduated from the Medical College of Glasgow and Edinburgh in 1913. She overcame the prejudices of that era and the barriers imposed by society. During World War I, she joined the Royal Army Medical Corps and served at the $63^{\text {rd }}$ General Hospital in Malta. After the war, in 1920, she became Assistant Medical Officer in 'Poor Law Service' at St. Alfege's Hospital in Greenwich. Over the years she became an academic, a doctor and a scientist and, against formidable competition in 1932, she passed the test for London Membership of the Royal College of Physicians. Her name is forever associated with the "Miracle of Saint Alfege's Hospital", that is, the effect of administration of physostigmine to patients with myasthenia gravis. Mary Walker's clinical awareness and her calm but determined manner paved the way to the understanding and treatment of this disease, with an influence that extends to the present day.

Physostigmine is a highly toxic parasympathomimetic alkaloid extracted from the Calabar bean, which is indigenous to western Africa. It acts as a potent antagonist of atropine through a reversible anticholinesterase reaction. In 1876, Harnack demonstrated the effect of physostigmine for boosting the electrical stimulation of mammalian striated muscle ${ }^{1}$. Sixty-two years later, Mary Walker described and showed two cases of very severe myasthenia gravis that were drastically improved through administration of physostigmine and, later on, prostigmin. Although prostigmin (neostigmine) was better tolerated by the patients, Mary highlighted that the price of nine pence per vial rendered it difficult to use in daily practice. The presentation of the dramatic improvement of the myasthenia patients took place at the clinical meeting of the Royal Society of Medicine (Neurology) at the National Hospital, Queen Square, London, on 17 February 1938, and was published in detail ${ }^{2.3}$. Mary concluded that myasthenia gravis was the pathological effect of a substance that entered the circulation and caused abnormal fatigability via the acetylcholine in the neuromuscular junction ${ }^{4}$. Mary's observations were scientifically sound: she used placebo (saline) to confirm the effect of physostigmine and she established the dose-related effect of the drug. The Figure was taken from her first publication

${ }^{1}$ Universidade Metropolitana de Santos, Departamento de Neurologia, Santos SP, Brasil.

${ }^{2}$ Harvard Medical School, Spaulding Rehabilitation Hospital, Department of Physical Medicine and Rehabilitation, Charlestown, MA USA.

Correspondence: Yara Dadalti Fragoso; Departamento de Neurologia da Faculdade de Medicina da UNIMES; Avenida Conselheiro Nebias, 536; $11045-002$ Santos SP, Brasil; E-mail:yara@bsnet.com.br 

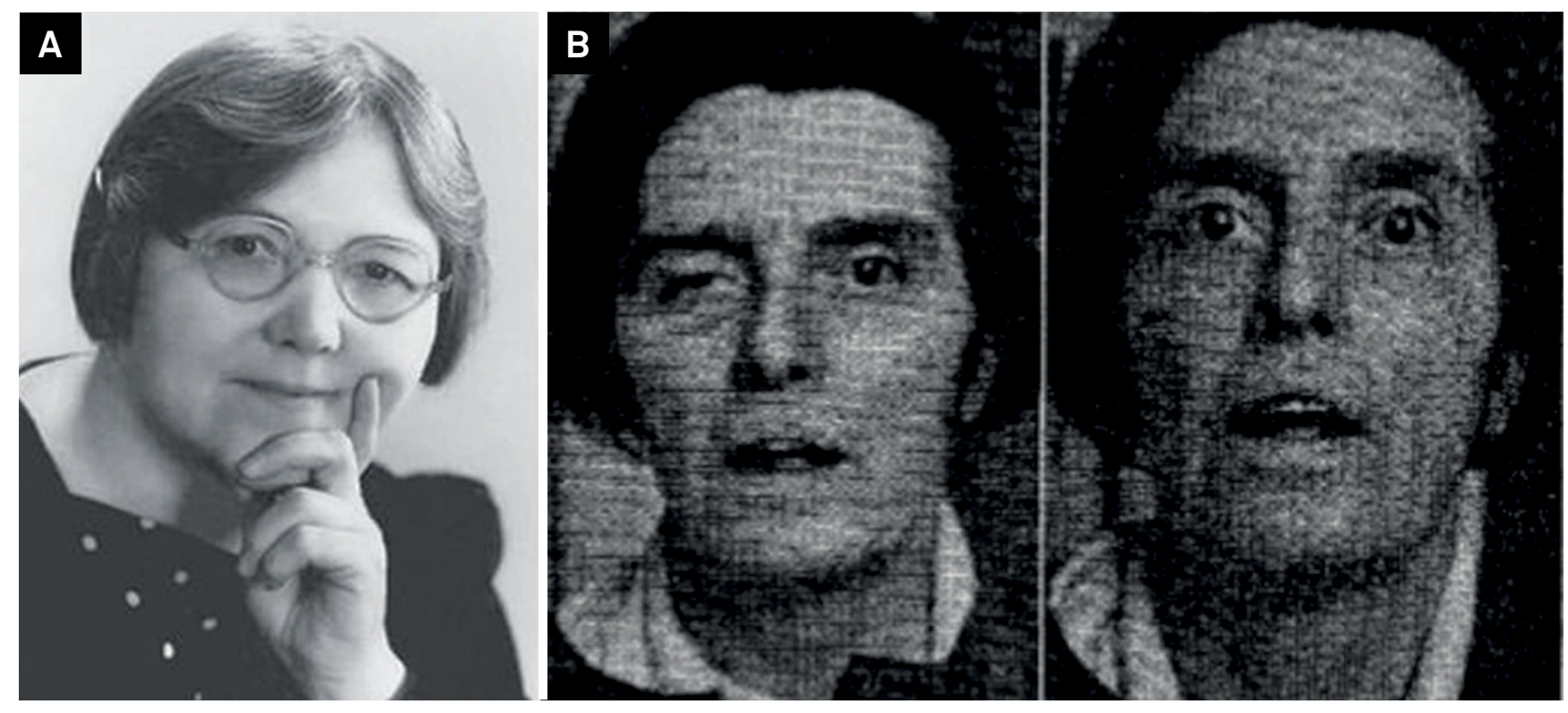

Figure. (A) Photo of Mary B. Walker; (1888-1974) (B) photo from her Letter to The Lancet in 1934, reporting on the dramatic effect of physostigmine on a patient with myasthenia gravis.

showing the effect of anticholinesterase agents on ptosis. The demonstration of her innovative treatment was immortalized in a movie produced in 1935, which is accessible online ${ }^{5}$.

The "Mary Walker effect" was later described and the humoral aspect of muscle tiredness was highlighted. The patient vigorously exercised the forearm with a tourniquet applied at the elbow. When the arm presented with muscle fatigue, the tourniquet was released and partial ptosis developed a few minutes later ${ }^{6}$. In addition, Mary was involved in the description of familial periodic paralysis and hypokalemia ${ }^{7}$.

Mary Walker's papers and presentations at the Royal Society of Medicine were received with a degree of skepticism and led to great discussion among the specialists of that era. The effect of this treatment was so dramatic and, at the same time, so short-lived, that it resembled nothing previously seen. The famous neurologist Denny-Brown, who earlier compared curare poisoning to myasthenia gravis (and this was how Mary thought of physostigmine as a potential treatment), stood against Mary's discoveries and explanations ${ }^{8}$. Others supported her findings, but she never received a Fellowship of the Royal College of Physicians and never occupied a teaching hospital position'. She was awarded the Jean Hunter Prize in 1962 "for the advancement of research into the treatment of nervous exhaustion and for her original contribution to the fundamental knowledge of the nature of myasthenia gravis, made while carrying out the routine duties of a medical officer at a large metropolitan hospital". Although it is now acknowledged that a German physician may have been the first to report on the effect of anticholinesterase agents in myasthenia gravis ${ }^{4}$, it was only through Mary B. Walker that the treatment became known, after detailed presentation of her results.

Mary retired to her native Scotland and died in comparative obscurity in Wigtown in 1974, at the advanced age of 86 years. She was surrounded by her cats and with neighbors who had the nicest words about the lady who had a walnut tree in her garden ${ }^{4,9,10}$.

Mary Broadfoot Walker was, perhaps, the only scientist to have made history with a " $n=1$ " treatment. Later she presented the second case, and " $n=2$ " was sufficient to convince others to try this therapy.

\section{References}

1. Sourkes TL. The Discovery of neurotransmitters and applications to neurology. Handb Clin Neurol. 2010;95:869-83. https://doi.org/10.1016/S0072-9752(08)02154-4

2. Walker MB. Treatment of myasthenia gravis with physostigmine. The Lancet 1934;1200-1.

3. Walker MB. Case showing the effect of prostigmin on myasthenia gravis. Proc R Soc Med. 1935;28(6):759-61.

4. Croitoru C, Turliuc D, Danciu F, Cucu A, Costea C. The miracle of St. Alfege's Hospital and the history of the treatment of myasthenia gravis. Rom Neurosurg. 2017;1:73-9. https://doi.org/10.1515/romneu-2017-0011

5. 1935 Prostigmin demonstration for MG. 2007 [cited 2017 Aug 1]. Available from: https://www.youtube.com/watch?v=uRoRsmvkhTI
6. Walker MB. Some discoveries on myasthenia gravis: the background. Br Med J. 1973;2(5857):42-3.

7. Aitken RS, Allot EN, Gastelden LIM, Walker MB. Observations on a case of familial periodic paralysis. Clin Sci. 1937;3:47-57.

8. Klawans, Harold L. Why Michael couldn't hit: and other tales of the neurology of sports. New York:W.H. Freeman; 1996.

9. Lee MR. The miracle of St. Alfege's: discovering a treatment for myaesthenia gravis. J Royal Soc Med. 2007;100(2):108-109.

10. Pearce JMS. Mary Broadfoot Walker (1888-1974): a historic discovery in myasthenia gravis. Eur Neurol. 2005;53:51-3. https://doi.org/10.1159/000084268 